\title{
PENGARUH GRAMMATICAL KNOWLEDGE TERHADAP SKOR LISTENING TOEFL TEST MAHASISWA PENDIDIKAN BAHASA INGGRIS UNIVERSITAS RIAU KEPULAUAN
}

\author{
Desi Surlitasari Dewi \\ English Dept., Universitas Riau kepulauan, Batam \\ Belldaisy46@gmail.com
}

\begin{abstract}
The aim of this research was to find out whether any effect of grammatical knowledge towards student's listening score in TOEFL Test. The design of the research was a correlational research that aims to find out whether any significant correlation of grammatical knowledge towards student's listening score in TOEFL Test. The population of the research was english department students of Universitas Riau Kepulauan and the sampe was taken by using purposive sampling. The number of the sample was 80 students. Data of the research were gathered by using test of grammatical knowledge and TOEFL Listening test. Those were the data of student's grammatical knowledge and student's listening score of TOEFL test. Based on the result of data analysis by using ttest, it was found out that student's grammatical knowledge affects their listening score in TOEFL test.
\end{abstract}

Keywords: grammatical knowledge, listening, TOEFL test

\begin{abstract}
Abstrak
Penelitian ini bertujuan untuk mengetahui adanya pengaruh dari grammatical knowledge terhadapkemampuan listening mahasiswa program studi pendidikan bahasa Inggris pada pengajaran TOEFL. Penelitian ini merupakan penelitian korelasi yang bertujuan untuk mengetahui apakah ada hubungan yang signifikan antara grammatical knowledge dan kemampuan listening mahasiswa program studi pendidikan bahasa Inggris pada pengajaran TOEFL. Penelitian ini menggunakan populasi seluruh mahasiswa Prodi Pendidikan Bahasa Inggris, Universitas Riau Kepulauan, Kepulauan Riau dan pemilihan sampel dilakukan dengan teknik purposive sampling. Adapun sampel yang digunakan yaitu mahasiswa semester akhir pada program studi pendidikan Bahasa Inggris yang berjumlah 80 mahasiswa. Data dikumpulkan dengan menggunakan tes grammar dan tes TOEFL. Data yang dihasilkan merupakan data mengenai grammatical knowledge dan kemampuan listening yang didapatkan melalui tes. Berdasarkan hasil analisa dengan menggunakan ttest, didapatkan hasil bahwa grammatical knowledge yang dimiliki oleh mahasiswa pendidikan Bahasa Inggris mempengaruhi skor listening yang mereka dapatkan dalam TOEFL test.
\end{abstract}

Kata kunci: grammatical knowledge, listening, TOEFL test

\section{PENDAHULUAN}


Test of English as Foreign Language atau yang biasa dikenal dengan TOEFL adalah tes standar untuk mengetahui kemampuan seseorang dalam menggunakan bahasa Inggris, baik receptive maupun productive skill, yang merupakan bahasa internasional dan salah satu bahasa resmi PBB, dimana banyak kegiatan-kegiatan internasional dilaksanakan dalam bahasa Inggris sehingga penting bagi akademisi untuk memiliki nilai TOEFL yang dipersyaratkan untuk dapat dinyatakan menguasai bahasa Inggris dengan memadai. Pada era globalisasi dan perdagangan bebas, memiliki nilai TOEFL yang tinggi merupakan syarat untuk dapat menuntut ilmu atau bekerja di negara lain, terutama yang menggunakan bahasa Inggris sebagai bahasa pengantar. Maka dari itu, bagi lembaga universitas, sangat penting untuk mempersiapkan lulusan yang berkompetensi tinggi dalam penguasaan bahasa asing dan dapat bersaing di tingkat dunia, salah satu tolok ukurnya adalah memiliki nilai TOEFL yang tinggi.

Salah satu alasan mengapa TOEFL test sangat penting dan mendunia yaitu karena tes ini berfungsi untuk memastikan bahwa seseorang dapat memahami kata-kata dalam bahasa inggris, mempergunakannya dengan benar baik secara lisan maupun tulisan, dimana hal ini penting ketika seorang akademisi ingin mempublikasikan karya ilmiahnya secara internasional. Seseorang yang memiliki skor TOEFL yang tinggi tentunya dipastikan dapat memahami buku-buku berbahasa Inggris sehingga dapat memiliki referensi-referensi yang bermutu dalam melakukan penelitian maupun menulis karya ilmiah.

Dalam TOEFL test, ada beberapa kemampuan yang diujikan misalnya yaitu kemampuan memahami bacaan dalam bahasa Inggris, atau yang dikenal sebagai reading test, dan structure and written expression yang mengukur kemampuan seseorang dalam mengenali bahasa Inggris sesuai standar penulisannya Selain itu terdapat listening test yaitu tes yang mengukur kemampuan seseorang dalam mendengarkan percakapan dalam bahasa inggris, yang mengandung beberapa unsur kebahasaan seperti penggunaan ungkapan, two and three part verbs yang memiliki arti berbeda dengan kata dasarnya., penggunaan kalimat wish (mengemukakan harapan) dan kalimat pengandaian. Selain percakapan pendek, terdapat juga percakapan panjang dan ceramah yang memuat beberapa informasi sekaligus yang harus dipahami oleh test taker.

Pengertian listening menurut Casperz dan Stasinka (2015: 1) adalah proses untuk menangkap kata-kata, mendengarkan, dan memahami suatu ujaran, tidak hanya apa yang 
diucapkan namun juga informasi tersirat yang disampaikan dalam ujaran tersebut. Sedangkan Nevers dan Witkowski (2004: 240) menyebutkan bahwa listening adalah sebuah proses yang mengintegrasikan pengetahuan, sikap, dan tingkah laku pendengar yang bersifat dinamis dan interaktif untuk mencapai suatu tujuan dalam kegiatan berkomunikasi.

Listening atau menyimak (mendengarkan), berbeda dengan hearing (mendengar), merupakan proses yang menuntut seseorang untuk aktif secara mental. (Low \& Sontag, 2013). Hal ini sesuai dengan teori yang dikemukakan oleh O’Malley, Chamot, dan Kupper (1989: 9) bahwa listening comprehension adalah proses yang aktif dan sadar dilakukan manusia dimana pendengar mengkonstruksikan makna dengan menggunakan petunjuk dari informasi konstekstual dan pengetahuan pendengar, yang menggunakan berbagai strategi dan sumber untuk dapat memenuhi tugas memahami dan merespon tersebut. Maka, dapat disimpulkan bahwa listening merupakan proses aktif dalam pikiran seseorang untuk mengkonstruksi arti atau makna dari suatu ucapan yang sedang didengarkan.

Hal-hal yang biasanya menghambat seseorang dalam tes listening, seperti yang disampaikan oleh Kassem (2015: 157) yaitu kecemasan seseorang dalam menghadapi tes listening, waktu mendengarkan yang sangat terbatas, kecepatan berbicara penutur yang dianggap terlalu cepat dengan aksen yang berbeda dengan pendengar, kurangnya pengetahuan tentang topik yang didengarkan, dan kurangnya pengetahuan tentang kosakata yang digunakan, serta struktur kalimat yang mengandung makna-makna tertentu.

Lebih lanjut, Kassem (2015) mengemukakan cara pengajaran listening yang efektif yaitu:

1. Pengajaran listening harus bersifat conscious atau sadar bahwa pembelajar sedang dipersiapkan untuk belajar mendengarkan bahasa asing dan dilaksanakan secara sistematis

2. Pengajaran listening harus dilaksanakan dalam praktek sehingga memberikan pengalaman nyata kepada pembelajar.

3. Pengajaran listening harus direncanakan. Dalam kegiatan mengajar, ada beberapa hal yang harus diantisipasi yaitu faktor-faktor yang menghambat listening yang efektif.

Berdasarkan penjelasan diatas, perlu diketahui faktor-faktor penghambat apa saja yang dapat mempengaruhi kemampuan listening seseorang.

Tes Listening yang digunakan untuk mengukur kemampuan listening siswa yaitu Paper Based TOEFL Test Longman (Phillips, 2001). Ada tiga jenis kemampuan yang diujikan 
dalam tes tersebut, yaitu kemampuan dalam memahami percakapan pendek serta implikasi dan arti dari ucapan-ucapan penutur. Tes ini berbentuk pilihan ganda dimana masing-masing percakapan pendek akan diikuti oleh satu pertanyaan. Kemampuan kedua yang diuji adalah pemahaman terhadap percakapan panjang. Tes ini berfungsi untuk mengukur kemampuan dalam memahami informasi detail dalam percakapan panjang. Sebuah percakapan panjang akan diikuti oleh beberapa pertanyaan. Dalam kedua jenis tes tersebut, topik biasanya berkisar dalam kehidupan sehari-hari.

Dalam penelitian ini, tes yang digunakan merupakan paper based TOEFL test (TOEFL PBT). Berdasarkan penjelasan dalam Educational Testing Service (ETS, 2008: 12), terdapat tiga bidang (section) yang diujikan, yaitu:

1. Listening Comprehension, yang mengukur kemampuan seseorang dalam memahami bahasa Inggris yang diucapkan oleh native speaker. Materi yang diujikan meliputi kosakata dan ungkapan-ungkapan, termasuk juga kalimat-kalimat dengan strukturstruktur tertentu yang sering digunakan oleh native speaker dalam percakapan.

2. Structure and Written Expression, yang mengukur kemampuan untuk mengenali penulisan standar yang benar dalam bahasa Inggris. Bahasa yang digunakan merupakan bahasa formal dan standar, dan bukan merupakan bahasa percakapan. Topik-topik dalam kalimat biasanya bersifat akademis namun umum sehingga dapat dipahami oleh semua kalangan di berbagai bidang ilmu.

3. Reading Comprehension, yang mengukur kemampuan seseorang untuk memahami teks bacaan pendek. Topik-topik dari bacaan tersebut biasanya adalah tentang kehidupan akademik. Masing-masing teks diikuti oleh beberapa pertanyaan, baik yang terdapat langsung dalam bacaan, maupun yang tersirat sehingga pembaca harus mengenali makna implisit dalam bacaan. Selain itu, terdapat juga pertanyaan tentang arti kata yang tidak familiar sehingga harus diketahui berdasarkan konteks bacaan.

Tabel 2.1 Nilai minimal dan maksimal dalam TOEFL Paper Based Test

\begin{tabular}{|c|l|c|c|}
\hline No & \multicolumn{1}{|c|}{ Section } & Minimal & Maksimal \\
\hline 1 & Listening Comprehension & 31 & 68 \\
\hline 2 & Structure and Written Expression & 31 & 68 \\
\hline
\end{tabular}




\begin{tabular}{|c|l|c|c|}
\hline 3 & Reading Comprehension & 31 & 67 \\
\hline 4 & Total & 310 & 677 \\
\hline
\end{tabular}

Berdasarkan tabel diatas, dapat diketahui bahwa nilai minimal dalam Paper based test yaitu 310 dan nilai maksimal yang dapat dicapai adalah 677. (Educational Testing Service, 2008: 13)

\section{A. METODE PENELITIAN}

Penelitian ini merupakan penelitian kuantitatif dengan menggunakan uji korelasi. Terdapat dua variabel yaitu grammatical knowledge sebagai variable $\mathrm{X}$ dan kemampuan listening sebagai variabel Y. Penelitian ini akan dilaksanakan dari bulan Desember 2016Maret 2017 di Program Studi Pendidikan Bahasa Inggris Universitas Riau Kepulauan, Provinsi Kepulauan Riau.

Populasi merupakan wilayah generalisasi yang terdiri atas objek/subjek yang mempunyai kualitas dan karakteristik tertentu yang ditetapkan oleh peneliti untuk dipelajari dan kemudian ditarik kesimpulan, sedangkan sampel adalah bagian dari jumlah dan karakteristik yang dimiliki oleh populasi tersebut. Populasi dalam penelitian ini adalah seluruh mahasiswa program studi Pendidikan Bahasa Inggris Universitas Riau Kepulauan, Kepulauan Riau yang berjumlah 328 mahasiswa. Sampel yang diambil merupakan mahasiswa tingkat akhir (semester7 atau 8) dimana mereka telah menguasai skill-skill dalam bahasa Inggris dan telah menerima pengajaran TOEFL.

Pengumpulan data dalam penelitian ini menggunakan grammar and structure test untuk mengetahui grammatical knowledge dan TOEFL Listening Test untuk mengetahui kemampuan listening siswa. Serta teknik dokumentasi untuk merekam segala aktivitas yang dilakukan di dalam penelitian. Sebelum pengumpulan data, maka dilakukan try out instrumen penelitian (grammar and structure test) untuk mengetahui tingkat validitas dan kesahihan instrumen penelitian dengan menggunakan pearson product moment untuk mengukur validitas soal dan KR-20 untuk mengetahui reliabilitas atau kesahihan tes. 
Setelah pengumpulan data, terlebih dahulu dilaksanakan tes normalitas dan homogeneitas untuk mengetahui bahwa data sampel normal dan homogen. Data berupa nilai grammar and structure dari tes grammar (Azar, 2007) yang merepresentasikan grammatical knowledge dan nilai TOEFL Listening Test yang merepresentasikan kemampuan Listening. Data kemudian diolah dengan menggunakan t-test untuk mengetahui signifikansi dari hubungan kedua variabel.

\section{HASIL PENELITIAN}

Berdasarkan data yang didapatkan dari tes grammatical knowledge dan tes listening, selanjutnya dilakukan ttest untuk mengetahui pengaruh dari grammatical knowledge terhadap skor listening dengan formula sebagai berikut.

$$
\begin{aligned}
& t=\frac{\bar{x}_{1}-\bar{x}_{2}}{\sqrt{\frac{s_{1}^{2}}{n_{1}}+\frac{s_{2}{ }^{2}}{n_{2}}}} \\
& t=\frac{50.17-44.67}{\sqrt{\frac{45.66}{30}+\frac{51.64}{30}}} \\
& t=\frac{5.50}{\sqrt{1.522+1.721}} \\
& t=\frac{5.50}{\sqrt{3.243}} \\
& t=\frac{5.50}{1 . .80} \\
& t=3.056
\end{aligned}
$$

Berdasarkan perhitungan yang dilakukan, didapatkan hasil bahwa ttest sebesar 3,056 lebih besar dari ttable yaitu sebesar 2,04 dengan level signifikansi atau toleransi kesalahan sebesar 5\%, maka dapat disimpulkan bahwa grammatical knowledge yang dimiliki oleh mahasiswa program studi pendidikan Bahasa Inggris mempengaruhi skor listening yang mereka dapatkan dalam TOEFL test. 


\section{KESIMPULAN}

Hasil ttest sebesar 3,056 lebih besar dari ttable yaitu sebesar 2,04 dengan level signifikansi atau toleransi kesalahan sebesar 5\%, maka dapat disimpulkan bahwa grammatical knowledge yang dimiliki oleh mahasiswa program studi pendidikan Bahasa Inggris mempengaruhi skor listening yang mereka dapatkan dalam TOEFL test. Hal ini berarti bahwa siswa yang memiliki grammatical knowledge yang tinggi memiliki nilai listening TOEFL yang lebih tinggi dibandingkan dengan mereka yang memiliki grammatical knowledge yang lebih rendah. Hal ini dapat terjadi karena dalam tes listening pada TOEFL test, terdapat beberapa materi yang kemungkinan tidak akan dipahami maknanya tanpa mengerti struktur kalimatnya, seperti negatives with comparatives yang mengandung makna superlative.

\section{DAFTAR PUSTAKA}

Azar, B. 2007. Grammar-based teaching: A practitioner's perspective. TESL-EJ, 11(2).

Caspersz, Donella \& Stasinka, Ania. 2015. Can we teach effective listening? An exploratory study. Journal of University Teaching and learning Practice, vol. 12, Issue 4, Article 2, pp. 1-13.

Kassem. . English Language Teaching Journal. Vol. 8, No. 2; 2015 p. 157. Retrieved November 1, 2016 from http://www.ccsenet.org/elt

Low, B E \& Sonntag, E 2013. Towards a pedagogy of listening: Teaching and learning from life stories of human rights violations. Journal of Curriculum Studies, vol. 45, no. 6, pp. 768789.

O’Malley, J., Chamot, A., \& Kupper, L. 1989. Listening comprehension strategies in second language acquisition. Applied Linguistics Journal, 10, pp. 418-437.

Phillips, Deborah. 2001. Longman complete course for the TOEFL test. Longman: New York. 
Thompson, K, Leintz, P, Nevers, B \& Witkowski, S 2004. The integrative listening model: An approach to teaching and learning listening. Journal of General Education, vol. 53, no. 34, pp. 225-247 